\title{
Key indicators of green competitiveness: the EU and Ukraine's performance
}

\author{
Olena Chygryn ${ }^{1}$, Oleksii Lyulyov ${ }^{1}$, Tetyana Pimonenko, ${ }^{1,}$, and Nataliya Myronenko ${ }^{2}$ \\ ${ }^{1}$ Department of Marketing, Sumy State University, 2, Rimski-Korsakov St, 40007, Sumy, Ukraine \\ ${ }^{2}$ Manager, McDonald's, Ukraine
}

\begin{abstract}
Implementation of the Global Sustainable Development Goals 2030 highlights the necessity to accelerate the dynamic processes of changing traditional approaches to doing business, favouring environmentally friendly and responsible ones. The article aims to research the structural environment of developing green competitiveness on the global level. The paper used the methods of structural analysis to determine the main drivers of forming green competitive advantages, correlation analysis for measuring links between the global sustainable competitiveness and countries' GDP per capita. The authors emphasise the country's level of green competitiveness described by the Global sustainable competitiveness index. The paper investigated the ability of Ukraine to generate competitive advantages by analysing key determinants connected with natural capital, resource intensity, intellectual capital, social cohesion, and governance compared to the world level. The analysis of the essential components of green competitiveness showed a significant number of organisational and economic prerequisites for its formation and improvement. The impacts of sustainable competitiveness on GDP increases over time. In that context it is essential to decide on economic and management policies following the promotion of green competitiveness results. The findings could be used for improving a basis for creating strategies for green competitiveness promotion on the countries' level.
\end{abstract}

\section{Introduction}

The scientific community has made a significant progress in identifying corporate competitive strategies [1-7] and instruments of company activities' ecologization [9-11]. A number of authors noticed that company's competitiveness results from providing socioeconomic macro-level policy [12-20]. A significant number of scientific schools investigate the features of energy policy and the ways and mechanism of implementing renewables [2129]. The authors [30] describe non-linear effects of supporting different financial sectors on energy efficiency. The authors investigated the new scientific horizons of renewable energy research [31]. The paper [32] investigated integral vectors of environmental, energy and

* Corresponding author: tetyana_pimonenko@econ.sumdu.edu.ua 
economic security showed the highest level of interaction between energy and environmental security and the lowest one between energy and economic security.

The unique role is devoted to implementing the SDGs in companies' activities and the national economy [33-37].

Nonetheless, current development trends were characterised by increasing the role of green competitive advantages in expanding the companies' market share. The authors in the papers [38-42] studied the influence of different economic and marketing instruments on companies' sustainability.

In addition, current trends in the business sector were characterised by the growth of green production, and as a result, the formation of green competitiveness of enterprises [43-49]. The researchers [50-55] justified why economic and marketing determinants of the competitive advantages formation have a significant value for creating a new potential and growing market share for the companies. At the same time, many scientific articles describe linkages between environment and economic indicators [56-129]. Thus, it is essential to study the structural environment of developing green competitiveness.

\section{Methodology}

It is proposed to undertake a structural analysis for determining the main drivers of forming green competitive advantages. In the process of research, green competitiveness will involve five components identified as: natural capital, resource intensity, intellectual capital, social cohesion and governance. To assess linking between the global sustainable competitiveness and countries' GDP per capita, Pearson correlation was calculated. The data from the Global Competitiveness Report will be used for measuring Ukraine's performance in the field of creating green competitiveness advantages.

\section{Research results}

A detailed analysis of the level of green competitiveness of the business sector requires determining the content of the main determinants that describe the five main components of sustainable competitiveness: natural and social capital, resource management, intellectual capital and innovation, governance efficiency.

Countries' green competitiveness has been described by the Global Sustainable Competitiveness Index (GSCI) since 2016. The main components of the global green competitiveness index have a structured system and include indicators of natural capital, resource intensity, intellectual capital, social cohesion, and governance. Unlike the Global Competitiveness Index (GCI), GSCI includes indicators which describe the natural capital of a country connected with the availability of resources and the level of the depletion of those resources, the efficiency of resource use. A comparison of the GSCI and GCI is represented in Figure 1. 


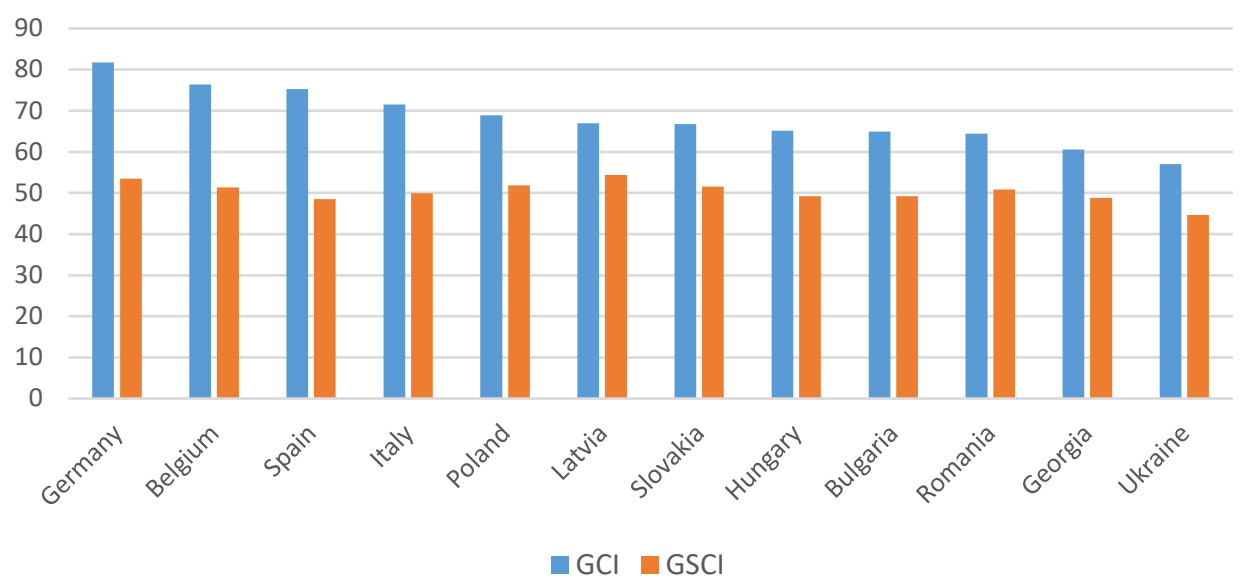

Fig. 1. Countries' ratings according to GCI and GSCI, 2019.

Source: composed by the authors, based on [131,132].

The corresponding lag of the GSCI from the GCI can be explained by several factors related to the specific features of technological development of national economies, the degree of perception of global sustainable development problems, and the economic system's ability to adapt to new development requirements.

Therefore, it is essential to understand which main components create the GSCI and assess green competitiveness.

Indicators of natural capital consist of five groups, which contain the following subgroups of indicators:

- agriculture, which is determined by the available land resources, the efficiency of agriculture production, yield, land degradation and the level of their desertification;

- biodiversity, which includes available information on forest resources, bioresources, the level of their depletion and anthropogenic pressure;

- water resources: their structure, renewables and non-renewables, a system of water use;

- mineral resources: condition and availability of energy and mineral resources, the level of resource exhaustion;

- environmental pollution: reflects the level and features of pollution of various resources, air.

At the same time, the experience [11] of using the economic and organisational instruments shows that the relevant instruments can be considered stimulants that have a positive meaning and those that are defined as "negative stimulants". Incentives include implementing resource-saving technologies, recycling, green production, socially responsible business management, green ethics and culture, digitalisation of green marketing, effective communication of stakeholders. In turn, harmful stimulants include environmental standards and regulations, prohibitions and restrictions, penalties, "user pays" and "polluter pays" principles.

The sub-index related to the effectiveness of the system of public management of green competitiveness covers aspects related to the strategic direction of government development and is determined by the following components: a system of state regulation and its infrastructure and compliance with sustainable development, state, business regulation system, the flexibility of management system changes, government cohesion, etc. 
It should be noted that the main target of public governance should be to ensure a stable environment for the economy and society to function and interact. At the same time, the game's clear and transparent rules will help both maintain the overall competitiveness of the business sector and ensure the green competitiveness of enterprises. Sustainable economic development requires the rule of law, increasing the pace and volume of investment in green technologies and approaches [128].

Such competitive advantages will be provided by:

- the presence of stable state institutions;

- transparent and effective legal framework;

- relevant environmentally-oriented state regulation and environmental taxation;

- the presence of developed capital markets (including the green investment market, stock market);

- the absence of corruption and bureaucracy, the focus of government agencies on helping the business sector in implementing clean production projects, promoting resource conservation;

- balanced distribution of state budget funds, state support for investment in environmentally friendly activities;

- availability of efficient and developed infrastructure for commercial and recreational purposes (transport, education, health care, recreation);

- cooperation among the business sector, educational and scientific institutions and government agencies.

These components should be the basis for setting the targets of state regulatory policy.

Ensuring and promoting green competitiveness is related to the availability and level of development of intellectual capital and innovation. Therefore, the assessment of green competitiveness contains the following sub-indices, which assess the functioning of the following areas [129]:

- education: mechanism of enrolment in schools, schools' performance, development of educational infrastructure;

- research and development: significant scientific areas, science funding, state support of higher education, the efficiency of the education system;

- business opportunities: simplicity of new business registration, development of hightech production, famous trademarks. An important indicator of sustainable competitiveness is the ability to support economic growth in economic and political instability conditions, rising prices in world commodity markets [9, 12929]. In this perspective, the Global Sustainable Competitiveness Index assesses the intensity of using various resources:

- energy: level of fossil fuels, electricity production, renewables;

- water: water use, drainage systems development, the efficiency of water using;

- raw materials: the number of resources, resources per GDP, resource balance.

The next group of the GSCI was selected to measure social cohesion, which contains additional indicators to assess:

- healthcare system: availability of medical services, level of mortality, principles of family planning;

- equality features: the level of income and their equality, resource availability, gender equality;

- crime: the level and structure of crimes, the number of people in prison;

- level of freedom: transparency in society, freedom of the press, development of human rights, contradictions and conflicts in society;

- level of satisfaction: index of happiness, the quantity of suicide rate, satisfaction with public service.

Thus, the study of the main components of the GSCI will identify problematic and promising vectors of the business sector development in the national economy. 
Assessing the level of sustainable competitiveness of the Ukrainian business sector as the ability to generate and sustain economic growth without reducing the potential of future generations allowed concluding the following (see Table 1).

Table 1. General preconditions for forming green competitiveness of Ukraine, 2020.

\begin{tabular}{|c|c|c|c|}
\hline Indicator & Ukraine & \multicolumn{2}{|c|}{ GSCI } \\
\hline Population, mln & 44,6 & \multirow{2}{*}{ Index } & \multirow{2}{*}{46.7} \\
\hline Territory, $\mathrm{km}^{2}$ & 603550 & & \\
\hline GDP per capita, $\$$ & 3719 & \multirow{2}{*}{$\begin{array}{l}\text { Global } \\
\text { rating }\end{array}$} & \multirow{2}{*}{76} \\
\hline GDP, bln $\$$ & 155.0 & & \\
\hline
\end{tabular}

Source: composed by the authors, based on the [128,129].

It should be noted that according to the results of the general assessment of Ukraine, the rating of sustainable competitiveness is at the level of average indicators. Figure 2.6 shows the position of Ukraine in comparison with the best rating of Sweden, which has 60.6 points in the ranking of sustainable competitiveness and an average score of 44.7.

Management decisions to increase the green competitiveness of the business sector of Ukraine require a detailed analysis of individual components of the GSC indicator. GSCI component related to natural capital is presented in Figure 2.

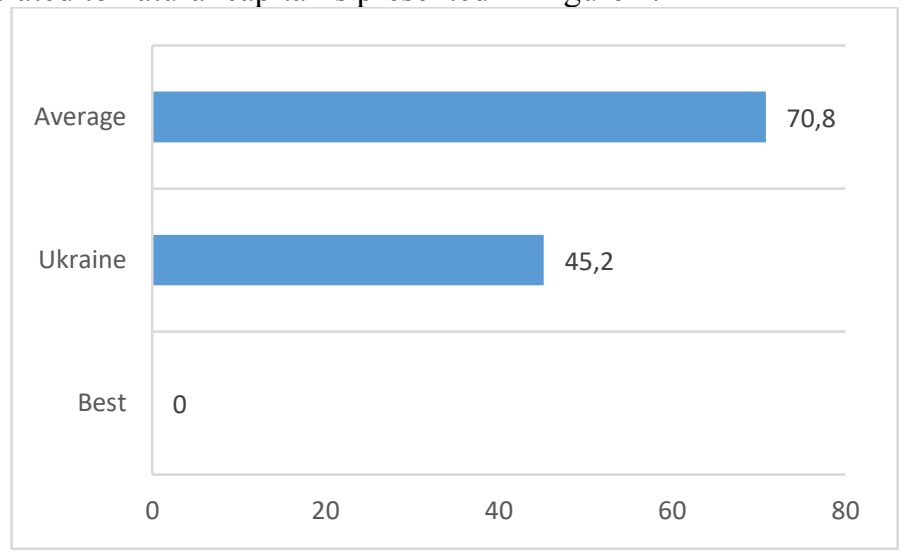

Fig. 2. Assessment of the natural capital of Ukraine in the rating of green competitiveness, 2019.

Source: composed by the authors, based on the Global Sustainable Competitiveness Report.

As it can be seen from the diagram, in terms of the natural capital, Ukraine has exceeded the average indicator (Spain, Montenegro) by $2.5 \%$ and lags behind the best indicator (for Great Britain Islands) by $45 \%$.

For individual components of the natural capital, the analysis results are presented in Figures 3-5.

Results show that this figure is only $12 \%$ of the world average, which characterises the relatively low natural potential of freshwater supply in Ukraine. It necessitates the introduction and promotion of approaches and technologies to find alternative sources of freshwater, introduction and use of modern wastewater treatment technologies. The number of people affected by the climate change is shown in Figure 5. 


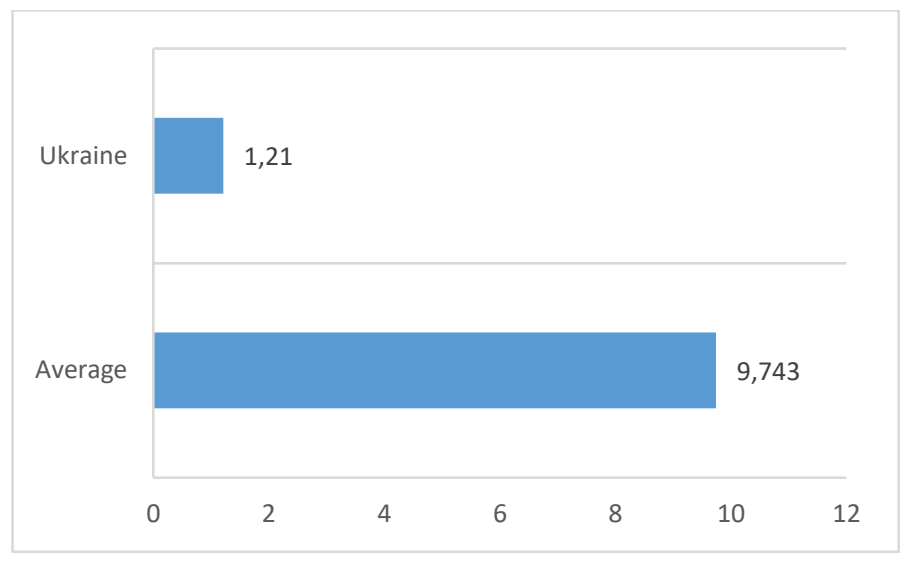

Fig. 3. Availability of fresh water, $2019\left(\mathrm{~m}^{3} /\right.$ person/year $)$.

Source: composed by the authors, based on $[128,129]$.

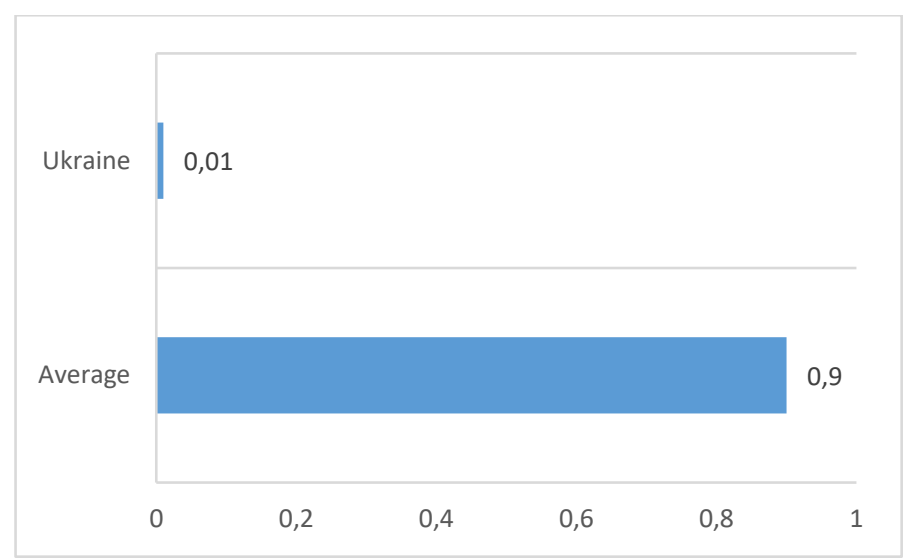

Fig. 4. Population affected by the climate change, 2019.

Source: composed by the authors, based on $[128,129]$.

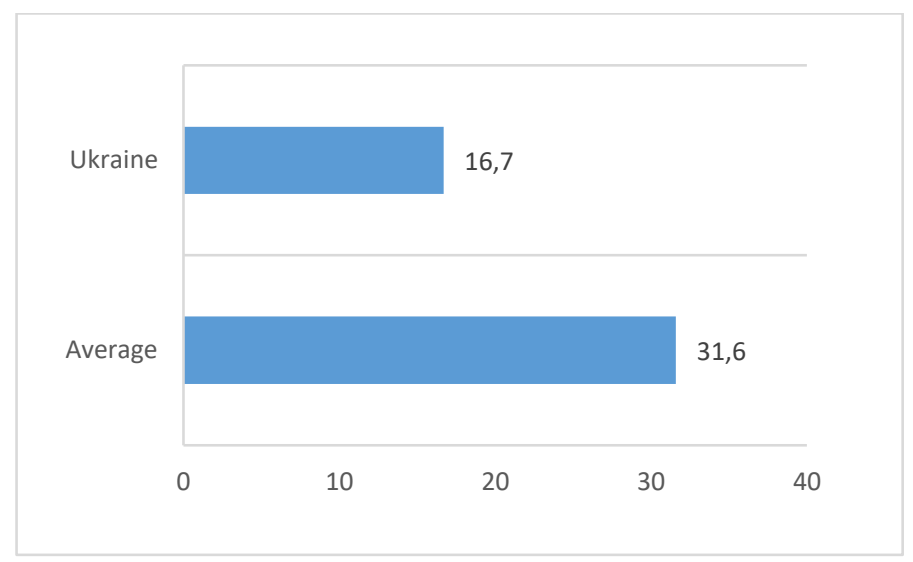

Fig. 5. Forest area, 2019, \%.

Source: composed by the authors, based on $[128,129]$. 
According to the rating, the percentage of Ukraine's population affected by the climate change is minimal. However, it should be noted that the part of the Ukrainian territory that is in the zone of hostilities may, to some extent, be considered a territory of ecological catastrophe.

Figure 6 shows the data on forest resource areas.

Even though Ukraine is a country with significant forest resources, domestic forestry indicators lag behind the world average.

The second component, which shows resource use efficiency, is characterised by the following indicators (Fig. 6). The analysed trends indicate a low level of using available water resources and low energy efficiency. Thus, Ukraine's energy efficiency is almost three times lower than the world average and accounts for $29 \%$ of the world average. However, the scale of $\mathrm{CO}^{2}$ emissions is at the world index level, which occurs against the background of the decline in industrial output of the national economy [129].

Therefore, there is no stable correlation between indicators of water efficiency and the development of renewable energy.

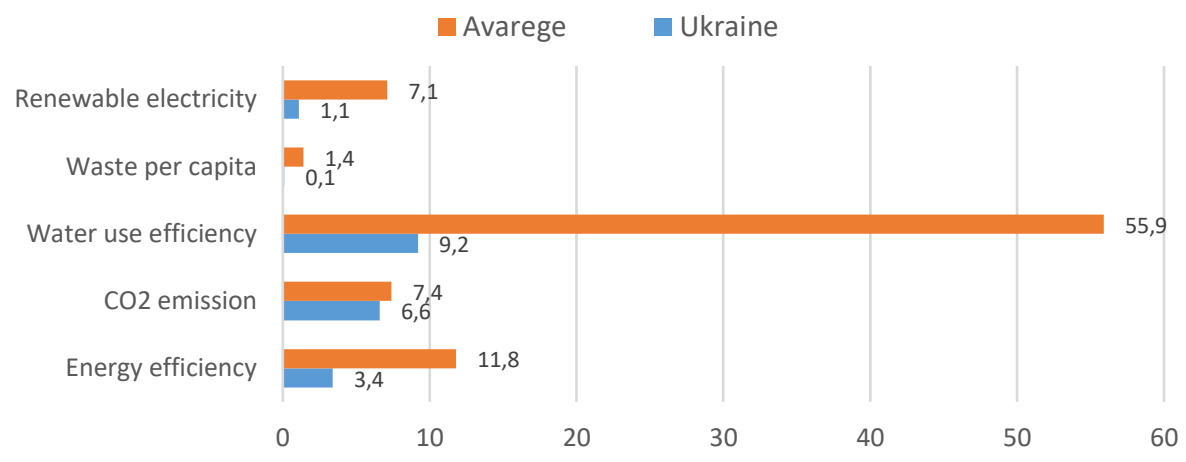

Fig. 6. Ukraine in the ranking of GSCI: resource efficiency, 2019.

Source: composed by the authors, based on $[128,129]$.

The efficiency of water use is only $16 \%$ of the world average, and the scale of renewable electricity is within $15 \%$ of the global average.

The next component that characterises green competitiveness is generating additional wealth and jobs through innovation and high value-added industries, which generally characterise the country's intellectual capital (Figures 7-10).

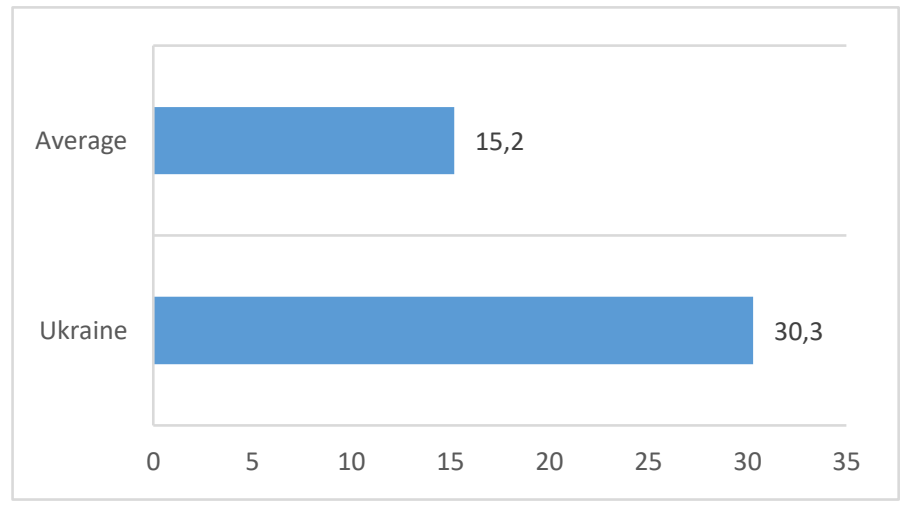

Fig. 7. Education expenditures, 2019.

Source: composed by the authors, based on $[128,129]$. 


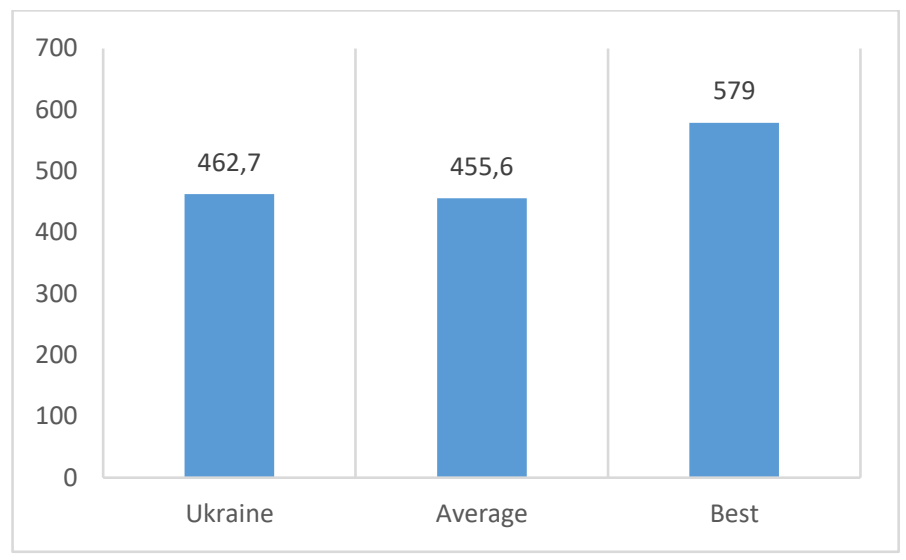

Fig. 8. PISA test results, 2019.

Source: composed by the authors, based on $[128,129]$.

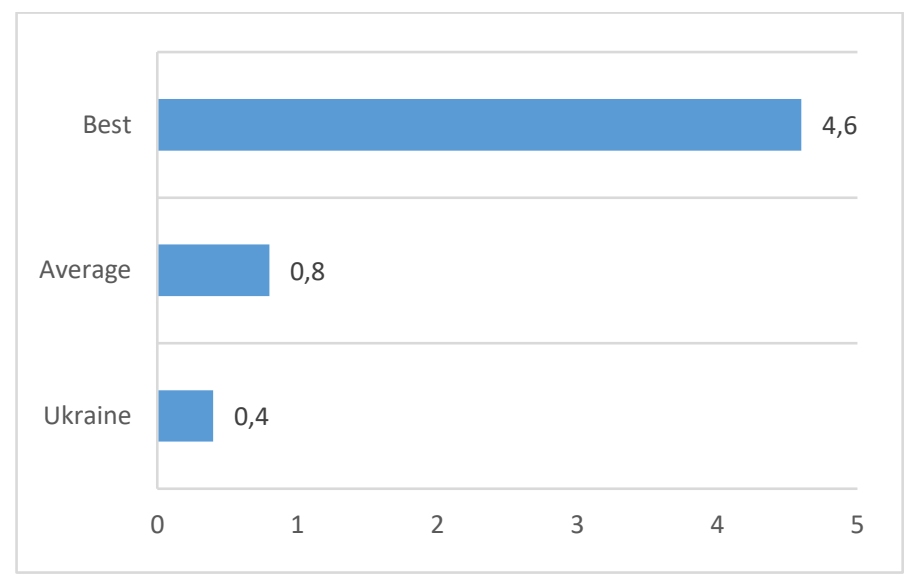

Fig. 9. Research and development costs (\% from GDP), 2019.

Source: composed by the authors, based on $[128,129]$.

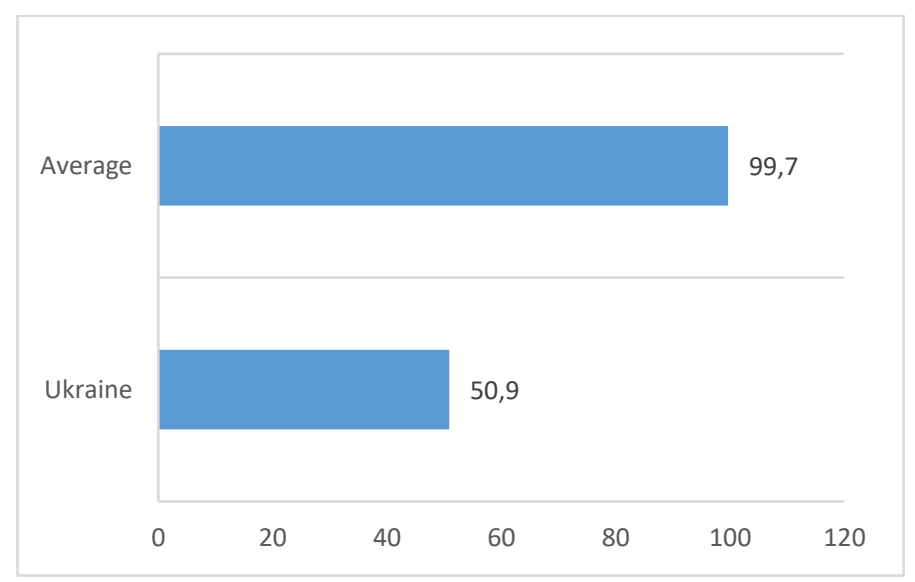

Fig. 10. The number of issued patents (units per 100,000 people), 2019.

Source: composed by the authors, based on $[128,129]$. 
First, the level of intellectual capital development is always associated with the cost of education. Thus, the cost of education in Ukraine is only $50 \%$ of the world average. The results of the PISA test indicate a high level of training of domestic students.

For the first time in 2018, Ukraine participated in the PISA test, which is a large-scale international study examining the quality of education and covers more than 80 countries, representing more than $80 \%$ of the world economy.

All countries of the Organization for Economic Cooperation and Development participate in the study, Ukraine being among them. PISA is not tied to educational programs. The study aims to determine the level of students' competencies and evaluates not the amount of theoretical knowledge but the ability of students to use the skills acquired in school in different life situations.

Thus, according to the assessment of competencies acquired by students, Ukraine exceeded the world average by $2 \%$, lagging behind the best indicator in the ranking accounting for $30 \%$. The appropriate level of this indicator shows positive trends in education, which determine the theoretical level of training and the ability to use the acquired knowledge in practice.

However, domestic spending on research and innovation development lags from the world average by $50 \%$, and from the highest level, they are only $8 \%$. This indicator shows the lack of support from the state and business structures for innovative development and sustainable competitiveness.

The number of registered patents per 100,000 people is also almost twice lower than the world average. The corresponding negative trend is characterised, to some extent, not by the lack of ideas and objects of patenting but by the complexity and high cost of the relevant procedure for obtaining patents. In addition, the state lacks effective mechanisms and procedures for protecting the relevant rights.

An important indicator that characterises the level of development of intellectual capital and innovation is the export of high-tech products. According to the world rating, only $8 \%$ of the world's best level and $65 \%$ are higher than the average.

Figure 11 shows the analysis of social capital as a component of the global index of green competitiveness. The key components are quality of health care, quality of life, gender issues, press transparency.

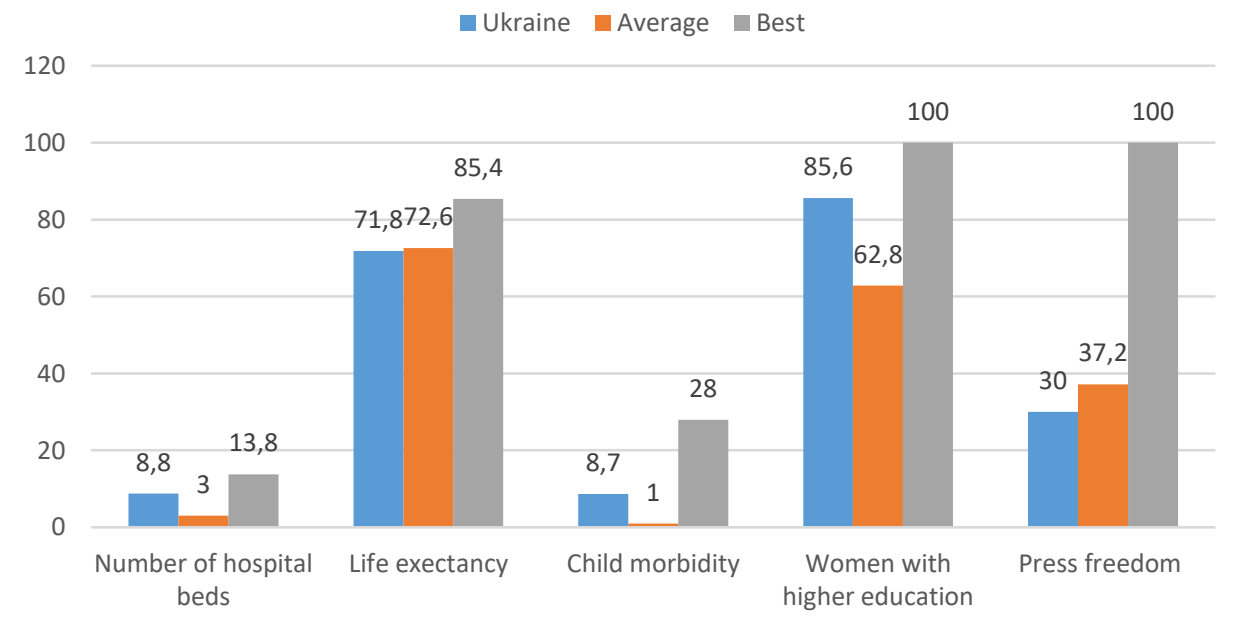

Fig. 11. Green competitiveness: social capital analysis, 2019.

Source: composed by the authors, based on $[128,129]$. 
Thus, according to the number of hospital beds, which determines, to some extent, the quality of health care, Ukraine is more than twice the average level. The corresponding trend is positive, but the quantitative component, in this case, does not fully determine the quality of hospital services.

Life expectancy in Ukraine is $2 \%$ lower than the world average of 72.6 years (for Ukraine, it is 71.8 years). Of concern is the infant mortality rate, which is eight times higher than the world average. A positive trend is observed in assessing the level of women's education. Thus, Ukraine, in this case, lags behind the best level by only $15 \%$.

The level of press freedom is only $30 \%$ of the best global level and lags behind the average by $19 \%$.

In general, the relevant trends in the state of social capital cannot form the basis and be thoroughly the drivers of increasing the green competitiveness of the business sector.

As a critical component of sustainable competitiveness, state regulation measures the efficiency of work in the main areas of the state - infrastructure, market structure and employment, corruption, resource allocation (Fig. 12).

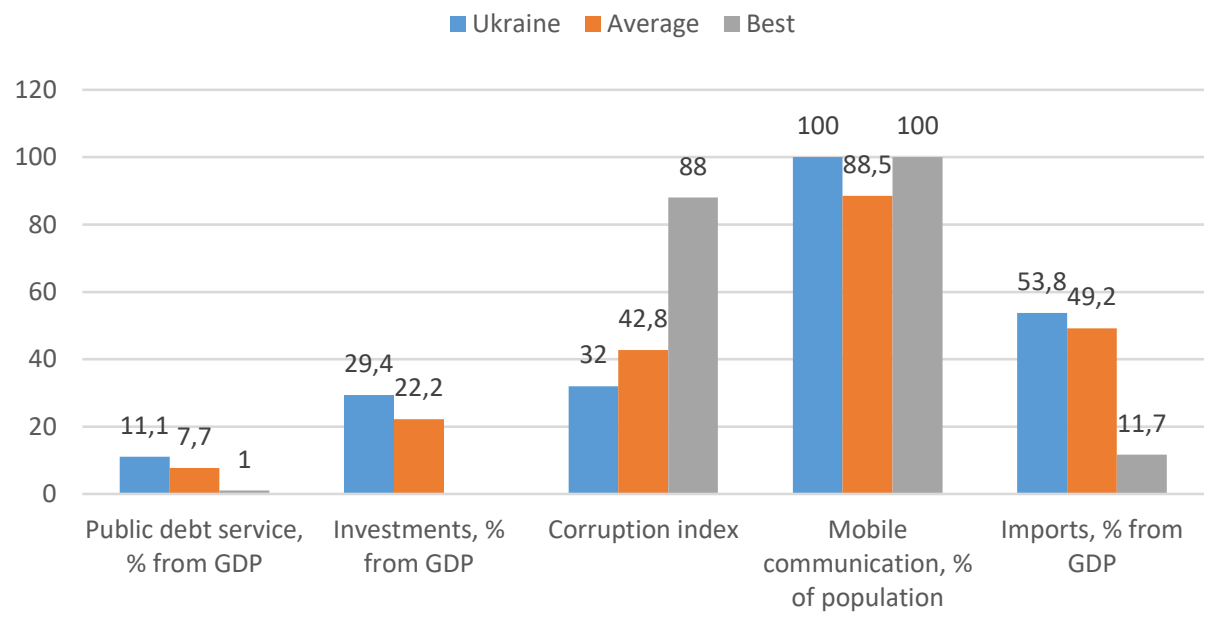

Fig. 12. Green competitiveness: governance analysis, 2019.

Source: composed by the authors, based on $[128,129]$.

The analysis of the public administration system in the context of forming green competitiveness allowed drawing the following conclusions.

The percentage of public debt service in Ukraine is 30\% higher than the world average. It indicates a high level of Ukraine's external debt and necessitates accumulation of significant financial resources to repay it, which in turn distracts from investing in development. Understandable in this context is the low level of investment (29.4 of GDP), which is only $32 \%$ higher than the world average of $22.2 \%$ of GDP.

The corruption index in Ukraine is 32 , which is a positive trend, as it is $32 \%$ lower than the average. A positive driver is the level of provision of the population with mobile communication, $100 \%$ in Ukraine. However, the level of goods' imports in the structure of the national economy is $53.8 \%$ of GDP. The corresponding value exceeds the average level by $9 \%$.

According to the evaluation results, the business sector of Ukraine cannot be described as sustainable and competitive, which is determined by high efficiency. The domestic system does not have appropriate approaches and measures that would increase efficiency and environmental competitiveness. The results of assessing the interdependence between the 
index of sustainable competitiveness and GDP per capita for the world (Fig. 13) revealed a corresponding correlation, in which Pearson's correlation coefficient was 0.5942 .

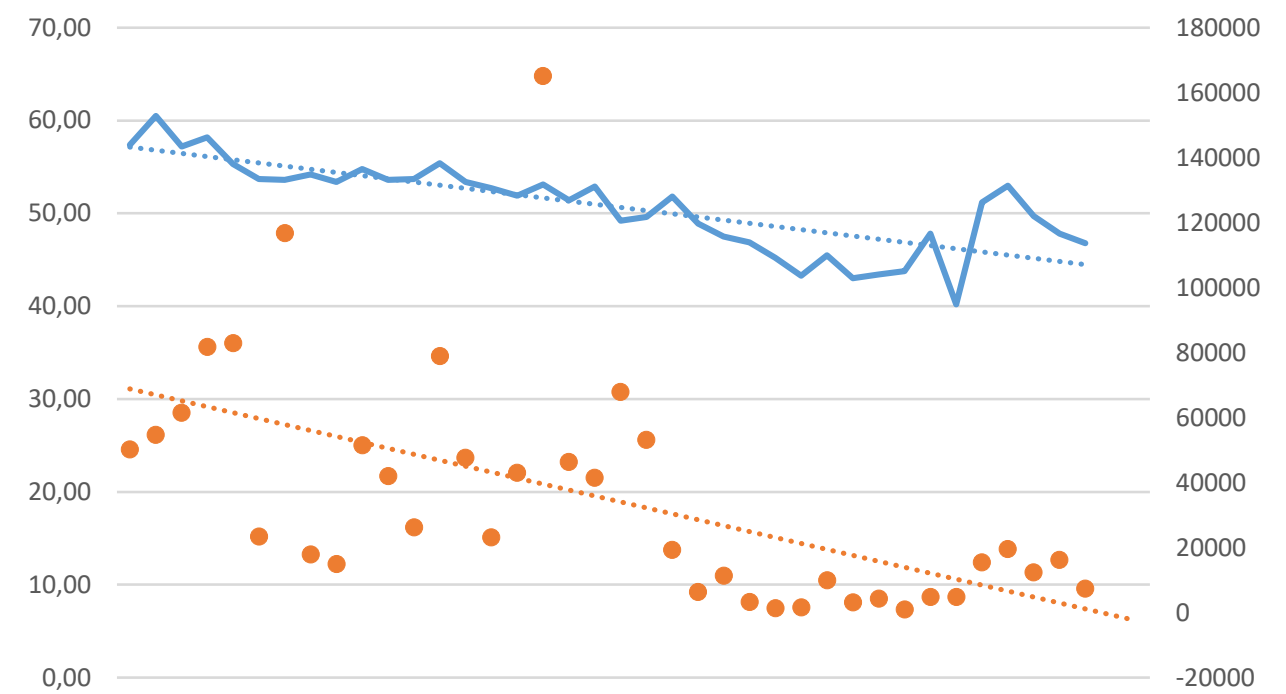

Fig. 13. The relationship between GSCI and GDP per capita for countries, 2019.

Source: composed by the authors, based on $[128,129]$.

It indicates a stable correlation between the analysed indicators. The analysis of the essential components of green competitiveness showed a significant number of organisational and economic prerequisites for its formation and improvement. In addition, it should be noted that the impact of sustainable competitiveness on GDP increases over time. Thus, it is essential to create and promote management and economic policies to increase the companies' green competitiveness.

\section{Conclusions}

Within the framework of the five main components of green competitiveness, a reasonable basis can be formed, which will ensure the development of the green competitiveness of enterprises in terms of the national economy functioning.

1. Natural capital management: creating appropriate legislation on protecting natural biodiversity; development of sustainable agriculture and land management for biodiversity restoration; protection of forest resources and reforestation; protection of water resources.

2. Resource intensity: implementation of environmental management, green standards, green accounting and audit, green funding, transfer of technologies, state support. Introduction of the "polluter pays" principle. Evaluation of environmental costs in a different way of production:

- development of green taxation, reinvestment in renewable energy technology and mitigation of climate change;

- maintaining the efficient use of resources based on a circular economy;

- supporting organic production.

3. Intellectual capital and implementation of innovation: creation of a national and regional economic strategy for supporting innovation and new approaches in education, information support, motivation business sector to implement green technologies, coordination the scientific research, providing high equal quality education, understanding 
of the modern skills in professional activities, development of professional training. Providing support and incentives for talented youth, sponsorship green programs, grants for education and local green projects.

4. Social cohesion and inclusion: development of the public health sector and growth of additional private medical services; integration and cooperation of law enforcement agencies with local communities, formation of related services to prevent crime; support for equal opportunities for all social groups and statuses; promotion of the inclusion principles, progression of modern approaches for employment and public participation in public services [10].

5. Public administration: building modern effective management mechanisms, providing transparency and responsibility of governance, clear legislation and legal framework; developing financial markets and instruments, supporting green investments to creating the green competitiveness of national economies and companies; ensuring a transparent taxation for business; financing the healthcare system, education and social infrastructure); developing transport infrastructure and other areas of public infrastructure (education, recreation); preventing corruption; harmonizing governance, economic, social and environmental issues.

\section{Funding}

This research was funded by the grant from the Ministry of Education and Science of Ukraine No 0119U101860, № 0120U102002, the National Research Foundation of Ukraine No 0120U104807 and 620232-EPP-1-2020-1-UA-EPPJMO-MODULE.

\section{References}

1. A. Bondarenko, L. Zakharkina, L. Syhyda, L. Saher. International Journal of Sustainable Development and Planning, 15(4), 439-449 (2020). doi:10.18280/ijsdp. 150404

2. A. Rosokhata. Marketing and Management of Innovations, 2, 43-53 (2014).

3. A. Kasych, M. Vochozka. Marketing and Management of Innovations, 2, 298305 (2017). 10.21272/mmi.2017.2-28

4. I. Myroshnychenko, I. Makarenko, D. Smolennikov, A. Buriak. TEM Journal, 8(3), 740-748 (2019). doi:10.18421/TEM83-07

5. L. Starchenko, Ya. Samusevych, K. Demchuk. Business Ethics and Leadership, 5(1), 118-126. (2021). https://doi.org/10.21272/bel.5(1).118-126.2021

6. I. Vakulenko, L. Saher, L. Syhyda, S. Kolosok, A. Yevdokymova. Paper presented at the E3S Web of Conferences, 234 doi:10.1051/e3sconf/202123400020

7. R. Miskiewicz. Energies, 13(22), 6106. (2020). https://doi.org/10.3390/en13226106

8. M. Taliento, A. Netti. Business Ethics and Leadership, 4(4), 123-131. (2020). https://doi.org/10.21272/bel.4(4).123-131.2020

9. I. Kendiukhov, M. Tvaronaviciene. Marketing and management of innovations, 3, 3342 (2017). DOI: 10.21272/mmi.2017.3-03

10. M. Han, H. Lin, J. Wang, Y. Wang, W. Jiang. Business Strategy and the Environment, 28 (6), 929-938 (2019).

11. M. Bublyk, V. Koval, O. Redkva. Marketing and Management of Innovations, 4, 229240 (2017). 10.21272/mmi.2017.4-20

12. L. Hrytsenko. Actual Problems of Economics, 159(9), 84-91 (2014) 
13. A. Teletov, S. Teletova, N. Letunovska. Periodicals of Engineering and Natural Sciences, 7(2), 458-465 (2019)

14. A. Boiko, I. Samusevych. Financial markets, institutions and risks, 1(1), 72-79 (2017). DOI: $10.21272 /$ fmir.1(1).72-79.2017

15. D. Li, M. Zheng, C. Cao, X. Chen, S., Ren, M. Huang. Journal of Cleaner Production, 141, 41-49 (2017).

16. K. Pająk, O. Kvilinskyi, O. Fasiecka, R. Miskiewicz. Economics and Environment, 2(61), 122-138 (2017)

17. S. Kolosok, V. Dementov, S. Korol, O. Panchenko. Journal of Applied Economic Sciences, 13(8), 2375-2384 (2018). Retrieved from https://www.scopus.com/record/display.uri?eid=2-s2.085063559158\&origin $=$ resultslist

18. V. Sukhonos, I. Makarenko, Y. Serpeninova, G. Qasimova. Problems and Perspectives in Management, 16(4), 126-140. (2018). doi:10.21511/ppm.16(4).2018.12

19. A. Vorontsova, T. Vasylieva, Y. Bilan, G. Ostasz, G., T. Mayboroda. Administratie Si Management Public, (34), 6-26. (2020). doi:10.24818/amp/2020.34-01

20. T. Vasileva, A. Lasukova. Corporate Ownership and Control, 10(4A), 86-93 (2013). doi:10.22495/cocv10i4art7

21. S. Kolosok, I. Myroshnychenko, H. Mishenina, I. Yarova. Paper presented at the E3S Web of Conferences, 234. (2021). doi:10.1051/e3sconf/202123400021

22. S. Kolosok, I. Myroshnychenko, L. Zakharkina. Paper presented at the CEUR Workshop Proceedings, 2732. 270-281. (2020) Retrieved from https://www.scopus.com/record/display.uri?eid=2-s2.0$\underline{85096133769 \& \text { origin }=\text { resultslist }}$

23. T. Vasylieva, V. Pavlyk, Y. Bilan, G. Mentel, M. Rabe. Energies, 14(5). (2021) doi:10.3390/en14051323

24. G. Mentel, T. Vasilyeva, Y. Samusevych, A. Vysochyna, R. Karbach, J. Streimikis. International Journal of Global Environmental Issues, 19(1-3), 177-195 (2020).

Retrieved from https://www.scopus.com/record/display.uri?eid=2-s2.0$\underline{85105783764 \& \text { origin }=\text { resultslist }}$

25. Ye. Ziabina, Ye. Kovalenko. SocioEconomic Challenges, 5(1), 117-132 (2021). https://doi.org/10.21272/sec.5(1).117-132.2021

26. Ye. Ziabina, T. Pimonenko, L. Starchenko. SocioEconomic Challenges, 4(4), 160174 (2020). https://doi.org/10.21272/sec.4(4).160-174.2020

27. H. Dzwigol, M. Dzwigol-Barosz. Academy of Strategic Management Journal, 19(5), 17. (2020).

28. H. Dzwigol, M. Dzwigol-Barosz, Z. Zhyvko, R. Miskiewicz, H. Pushak, Journal of Security and Sustainability Issues, 8(3), 307-317 (2019)

29. V. Pavlyk. Institutional Determinants Of Assessing Energy Efficiency Gaps In The National Economy. SocioEconomic Challenges, 4(1), 122-128 (2020). http://doi.org/10.21272/sec.4(1).122-128.2020.

30. O. Chygryn, V. Krasniak. Marketing and management of innovations, (3), 226-234 (2015).

31. A. Rosokhata, M. Minchenko, L. Khomenko, O. Chygryn. E3S Web of Conferences 250. (TRESP 2021). (2021). DOI: 10.1051/e3sconf/202125003002. 
32. Y. Samusevych, A. Vysochyna, T. Vasylieva, S. Lyeonov, S. Pokhylko. Paper presented at the E3S Web of Conferences, 234 (2021). doi:10.1051/e3sconf/202123400012

33. Y. Kharazishvili, A. Kwilinski, O. Grishnova, H. Dzwigol. Sustainability, 12(21), 8953 (2020)

34. A. Vorontsova, H. Shvindina, T. Mayboroda, H. Mishenina, I. Heiets. Problems and Perspectives in Management, 18(4), 275-288 (2020). doi:10.21511/ppm.18(4).2020.23

35. Y. Petrushenko, A., Vadym, A. Vorontsova, O. Ponomarenko. Paper presented at the E3S Web of Conferences, 202 (2020). doi:10.1051/e3sconf/202020203005

36. A. Artyukhov, I. Volk, T. Vasylieva, S. Lyeonov. Paper presented at the E3S Web of Conferences, 250 (2021). doi:10.1051/e3sconf/202125004006

37. S. Chen, G. Liao, B. Drakeford, P. Failler. Sustainability (Switzerland), 11(7), 1959 (2019). DOI:10.3390/su11071959

38. Y. Chen, A. Huang, T. Wang, Y. Chen. Total Quality Management and Business Excellence, 31(1-2), 194-209 (2020)

39. Y. Chen, C. Lin, C. Weng. Sustainability, 7(8), 10135-10152 (2015)

40. Y. Chen, T. Chang, C. Lin, Y. Lai, H., Wang. Sustainability, 8(10), 966 (2016)

41. L. Zhang, C. Cao, F. Tang, J. He, D. Li. Technology Analysis and Strategic Management, 31(2), 199-212 (2019)

42. J. Zhang, G. Liang, T. Feng, C. Yuan, W., Jiang, W. Business Strategy and the Environment, 29(1), 39-53 (2020). DOI https://doi.org/10.1002/bse.2349

43. O. Chygryn, A. Rosokhata, O. Rybina, N. Stoyanets. Paper presented at the E3S Web of Conferences, 234 (2021). doi:10.1051/e3sconf/202123400004

44. A. Rosokhata, O. Rybina, A. Derykolenko, V. Makerska. Research in World Economy, 11(4), 42-52 (2020).

45. N. Letunovska, L. Saher, T. Vasylieva, S. Lieonov. Paper presented at the E3S Web of Conferences, 250 (2021). doi:10.1051/e3sconf/202125004014

46. A. Vysochyna, N. Stoyanets, G. Mentel, T. Olejarz. Sustainability (Switzerland), 12(10) (2020). doi:10.3390/su12104090

47. T. Vasylieva, V. Machová, A. Vysochyna, J. Podgórska, Y. Samusevych. Journal of International Studies, 13(4), 273-285 (2020).doi:10.14254/2071-8330.2020/13-4/19

48. I. Didenko, K. Volik, T. Vasylieva, S. Lyeonov, N. Antoniuk. Paper presented the E3S Web of Conferences, 202 (2020)

49. A. Rosokhata, M. Minchenko, L. Khomenko, O. Chygryn. Paper presented at the E3S Web of Conferences, 250 (2021)

50. I. Didenko, K. Volik, T. Vasylieva, S. Lyeonov, N. Antoniuk. Paper presented at the E3S Web of Conferences, 234 (2021)

51. L. Saher, L. Syhyda, O., Korobets, T. Berezianko. Paper presented at the E3S Web of Conferences, 234 (2021)

52. T. Savchenko, V. Koibichuk, A. Boyko, M. Minchenko. Financial and credit activities: problems of theory and practice. 4(35), 37-43. (2020).

https://doi.org/10.18371/fcaptp.v4i35.221737

53. B. Gavurova, R. Bacik, R., Fedorko, M. Rigelsky. Marketing and Management of Innovations, (2), 186-200 (2018). 10.21272/mmi.2018.2-15

54. K. Djalilov, T. Vasylieva, S. Lyeonov, A. Lasukova. Corporate Ownership and Control, 13(1CONT8), 879-888 (2015). doi:10.22495/cocv13i1c8p7 
55. L. Syhyda. Economic Annals-XXI, 7-8(2), 28-32 (2013).

56. S. Leonov, O. Isaieva. Actual Problems of Economics, 155(5), 416-425 (2014).

Retrieved from https://www.scopus.com/record/display.uri?eid=2-s2.0$84906086267 \&$ origin $=$ resultslist

57. Y. Bilan, P. Srovnalã-KovÃi, J. Streimikis, S. Lyeonov, I. Tiutiunyk, Y. Humenna. Journal of Global Environmental Issues, 19(1-3), 196-216 (2020). Retrieved from https://www.scopus.com/record/display.uri?eid=2-s2.0$\underline{85105821876 \& \text { origin }=\text { resultslist }}$

58. G. Keliuotytė-Staniulènienè, K. Daunaravičiūtè. Financial Markets, Institutions and Risks, 5(1), 50-60 (2021). https://doi.org/10.21272/fmir.5(1).50-60.2021

59. V. Pavlyk. Financial Markets, Institutions and Risks, 4(1), 117-123 (2020). http://doi.org/10.21272/fmir.4(1).117-123.2020

60. A. El Amri, S. Oulfarsi, R. Boutti, A. Sahib Eddine, A. Hmioui. Financial Markets, Institutions and Risks, 5(1), 5-17 (2021). https://doi.org/10.21272/fmir.5(1).5-17.2021

61. H. Shuquan. Business Ethics and Leadership, 3(4), 43-48 (2019). http://doi.org/10.21272/bel.3(4).43-48.2019

62. S. Cyfert, A. Chwiłkowska-Kubala, W. Szumowski, R. Miśkiewicz, PLoS ONE, 16(4), e0249724 (2021)

63. B. Czyżewski, A. Matuszczak, R. Miskiewicz, Technological and Economic Development of Economy, 25(1), 82-102 (2019)

64. H. Dzwigol, M. Dzwigol-Barosz, R. Miskiewicz, A. Kwilinski, Entrepreneurship and Sustainability Issues, 7(4), 2630-2644 (2020)

65. E. Gross-Golacka, M. Kusterka-Jefmanska, R. Miskiewicz, B. Jefmanski, A. Rzepka, T. Kupczyk, European Research Studies Journal, XXIV(2B), 410-429 (2021)

66. L. Hrytsenko, I. Boiarko, O. Tverezovska, J. Polcyn, R. Miskiewicz, Marketing and Management of Innovations, 2, 155-165 (2021)

67. R. Miskiewicz, Polityka Energetyczna, 21(2), 49-62 (2018)

68. R. Miskiewicz, Virtual Economics, 2(2), 37-47 (2019)

69. R. Miskiewicz, Marketing and Management of Innovations, 3, 371-381 (2020)

70. R. Miśkiewicz, Journal of Risk and Financial Management, 14(2), 59 (2021)

71. R. Miśkiewicz, R. Wolniak, Sustainability, 12(14), 5776 (2020)

72. O. Prokopenko, R. Miskiewicz, Entrepreneurship and Sustainability Issues, 8(2), 269284 (2020)

73. A. Rzepka, R. Borowiecki, R. Miskiewicz, Z. Olesinski, European Research Studies Journal, XXIV(2), 1149-1162 (2021)

74. P.W. Saługa, K. Szczepańska-Woszczyna, R. Miśkiewicz, M. Chłąd, Energies, 13(18), 4833 (2020)

75. H. Dźwigoł, Virtual Economics, 4(1), 98-117 (2021)

76. H. Dzwigol, Marketing and Management of Innovations, 1, 128-135 (2020)

77. H. Dzwigol, Academy of Strategic Management Journal, 19(4), 1-8 (2020)

78. H. Dzwigol, Marketing and Management of Innovation, 1, 324-335 (2021)

79. H. Dzwigol, R. Wolniak, Przemysl Chemiczny, 97(7), 1114-1116 (2018)

80. H. Dzwigol, S. Shcherbak, M. Semikina, O. Vinichenko, V. Vasiuta, Academy of Strategic Management Journal, 18(SI1), 1-8 (2019) 
81. H. Dzwigol, O. Aleinikova, Y. Umanska, N. Shmygol, Y. Pushak, Journal of Entrepreneurship Education, 22(1S), 1-7 (2019)

82. H. Dzwigol, M. Dźwigoł-Barosz, A. Kwilinski, International Journal of Entrepreneurship, 24(1), 1-5 (2020)

83. Y. Kharazishvili, A. Kwilinski, O. Sukhodolia, H. Dzwigol, D. Bobro, J. Kotowicz, Energies, 14(8), 2126 (2021)

84. Y. Kharazishvili, A. Kwilinski, H. Dzwigol, V. Liashenko, Virtual Economics, 4(2), 740 (2021)

85. A. Kwilinski, O. Vyshnevskyi, H. Dzwigol, Journal of Risk and Financial Management, 13(7), 142 (2020)

86. H. Dzwigol, M. Dźwigoł-Barosz, Financial and Credit Activity: Problems of Theory and Practice, 2(25), 424-437 (2018)

87. A. Kwilinski, H. Dzwigol, V. Dementyev, International Journal of Entrepreneurship, 24(1), 1-5 (2020)

88. O. Arefieva, O. Polous, S. Arefiev, V. Tytykalo, A. Kwilinski, IOP Conference Series: Earth and Environmental Science, 628, 012039 (2021)

89. V. Boiko, A. Kwilinski, M. Misiuk, L. Boiko, Economic Annals-XXI, 175(1-2), 68-72 (2019)

90. S. Bogachov, A. Kwilinski, B. Miethlich, V. Bartosova, A. Gurnak, Entrepreneurship and Sustainability Issues, 8(2), 487-499 (2020)

91. O. Chygryn, Y. Bilan, A. Kwilinski, Marketing and Management of Innovations, 3, 356-368 (2020)

92. N. Dalevska, V. Khobta, A. Kwilinski, S. Kravchenko, Entrepreneurship and Sustainability Issues, 6(4), 1839-1860 (2019)

93. V.V. Dementyev, A. Kwilinski, Journal of Institutional Studies, 12(1), 100-116 (2020)

94. V. Khrapkina, A. Kwilinski, J. Polcyn, K. Pająk, V. Stratonov, V. Kobets, V. Virtual Economics, 4(2), 41-73 (2021)

95. V. Koibichuk, N. Ostrovska, F. Kashiyeva, A. Kwilinski, Marketing and Management of Innovations, 1, 253-265 (2021)

96. V. Kondratenko, O. Okopnyk, L. Ziganto, A. Kwilinski, Marketing and Management of Innovations, 1, 87-94 (2020)

97. A. Kuzior, A. Kwilinski, V. Tkachenko, V. Entrepreneurship and Sustainability, 7(2), 1353-1376 (2019)

98. A. Kuzior, A. Kwilinski, I. Hroznyi, Energies, 14(9), 2572 (2021)

99. A. Kuzior, O. Lyulyov, T. Pimonenko, A. Kwilinski, D. Krawczyk, Sustainability, 13(15), 8145 (2021)

100.A. Kwilinski, Virtual Economics, 1(1), 7-25 (2018)

101.A. Kwilinski, Marketing and Management of Innovations, 4, 116-128 (2018)

102.A. Kwilinski, Academy of Accounting and Financial Studies Journal, 23(SI2), 1-6 (2019)

103.A. Kwilinski, V. Tkachenko, A. Kuzior, Journal of Security and Sustainability Issues, 9(2), 561-570 (2019)

104.A. Kwilinski, N. Dalevska, S. Kravchenko, I. Hroznyi, I. Kovalenko, Journal of Entrepreneurship Education, 22(SI1), 1-7 (2019) 
105.A. Kwilinski, I. Ruzhytskyi, V. Patlachuk, O. Patlachuk, B. Kaminska, Journal of Legal, Ethical and Regulatory Issues, 22(SI2), 1-6 (2019)

106.A. Kwilinski, R. Volynets, I. Berdnik, M. Holovko, P. Berzin, P. Journal of Legal, Ethical and Regulatory Issues, 22(SI2), 1-6 (2019)

107.A. Kwilinski, K. Pajak, O. Halachenko, S. Vasylchak, Y. Pushak, P. Kuzior, Marketing and Management of Innovations, 4, 172-181 (2019)

108. A. Kwilinski, A. Kuzior, Management Systems in Production Engineering, 28(2), 119$123(2020)$

109.A. Kwilinski, Y. Zaloznova, N. Trushkina, N. Rynkevych, E3S Web of Conferences, 168, $00031(2020)$

110.A. Kwilinski, M. Dielini, O. Mazuryk, V. Filippov, V. Kitseliuk, Journal of Security and Sustainability Issues, 10(1), 345-358 (2020)

111.A. Kwilinski, D. Shteingauz, V. Maslov, Financial and Credit Activities: Problems of Theory and Practice, 3(34), 133-140 (2020)

112.A. Kwilinski, I. Slatvitskaya, T. Dugar, L. Khodakivska, B. Derevyanko, International Journal of Entrepreneurship, 24(1 Special Issue), 1-8 (2020)

113.A. Kwilinski, V. Litvin, E. Kamchatova, J. Polusmiak, D. Mironova, International Journal of Entrepreneurship, 25(1), 1-8 (2021)

114. Y. Kyrylov, V. Hranovska, V. Boiko, A. Kwilinski, L. Boiko, L. Journal of Risk and Financial Management, 13(12), 303 (2020)

115.V. Lakhno, V. Malyukov, T. Bochulia, Z. Hipters, A. Kwilinski, O. Tomashevska, International Journal of Civil Engineering and Technology, 9(8), 1802-1812 (2018)

116.K. Pająk, B. Kamińska, O. Kvilinskyi, O. Financial and Credit Activity: Problems of Theory and Practice, 2(21), 204-217 (2016)

117.T. Savchenko, N. Basiurkina, O. Rodina, A. Kwilinski, Management Theory and Studies for Rural Business and Infrastructure Development, 41(1), 43-61 (2019)

118.V. Tkachenko, A. Kwilinski, O. Korystin, N. Svyrydiuk, I. Tkachenko, Journal of Security and Sustainability, 8(3), 375-385 (2019)

119. V. Tkachenko, A. Kwilinski, M. Klymchuk, I. Tkachenko, Management Systems in Production Engineering, 27(2), 119-123 (2019)

120.V. Tkachenko, A. Kwilinski, I. Tkachenko, P. Puzyrova, Marketing and Management of Innovations, 2, 228-238 (2019)

121.V. Tkachenko, A. Kwilinski, B. Kaminska, I. Tkachenko, P. Puzyrova, Financial and Credit Activity: Problems of Theory and Practice, 3(30), 85-94 (2019)

122.V. Tkachenko, A. Kuzior, A. Kwilinski, Journal of Entrepreneurship Education, 22(6), 1-10 (2019)

123.L.M. Karpenko, M. Serbov, A. Kwilinski, V. Makedon, S. Drobyazko, Academy of Strategic Management Journal, 17(5), 1-7 (2018)

124.J. Polcyn, Management, 22(2), 171-186 (2018)

125.J. Polcyn, Sustainability, 13(15), 6846 (2021)

126.A. Zielińska-Chmielewska, A. Olszańska, J. Kaźmierczyk, E.V. Andrianova, Agronomy, 11(2), 299 (2021)

127.R. Abazov, Herald of Journalism, 58(4), 34-43 (2021)

128. Global Competitiveness Report (2019). Retrieved from http://www3.weforum.org/docs/WEF_TheGlobalCompetitivenessReport2019.pdf 
129. Global Sustainable Competitiveness Report (2019). Retrieved from

https://solability.com/the-global-sustainable-competitiveness-index/the-index

https://solability.com/the-global-sustainable-competitiveness-index/the-index 